\title{
WECHSLEROVA ZKRÁCENÁ PAMĚŤOVÁ ŠKÁLA Recenze metody
}

\author{
AUTOR RECENZE: Renata Hlavová1 ${ }^{,}$Anna Marie Rosická ${ }^{1}$ \\ Katedra psychologie, Fakulta sociálních studií Masarykovy univerzity
}

\begin{tabular}{|c|l|}
\hline datum vzniku recenze: & 30.11 .2017 \\
\hline 1.1 název nástroje: & Wechslerova zkrácená pamět’ová škála \\
\hline zkrácený název: & WMS-IIIa \\
\hline 1.2 původní název: & Wechsler Memory Scale - Third Edition Abbreviated \\
\hline 1.4 autoři původního testu: & David Wechsler \\
\hline 1.3 autoři lokální adaptace: & Adéla Jenčová, Dana Černochová \\
\hline 1.7 lokální distributor: & Hogrefe - Testcentrum \\
\hline $1.9 .1 / 1.9 .2$ datum vydání: & 2011 \\
\hline
\end{tabular}

\section{Obecné informace o metodě}

Česká adaptace Wechslerovy zkrácené pamět’ové škály (dále WMS-IIIa) je zkrácenou verzí třetí revize Wechslerovy pamět'ové škály (dále WMS-III). Zaměřuje se na orientační měření aktuálního fungování deklarativní epizodické paměti, konkrétně na pamět' sluchovou a zrakovou $\mathrm{z}$ hlediska bezprostředního a oddáleného vybavení (Wechsler, 2011). Je určena pro populaci ve věku 20-89 let. Dle autorů je metoda využitelná především v klinické praxi, a to pro screeningovou diagnostiku narušení paměti či jako součást komplexního psychologického nebo neuropsychologického vyšetření. Metoda byla $v$ anglické verzi testována na řadě klinických vzorků, měla by tedy umožňovat širokou oblast využití.

\section{Vývoj}

Východiskem pro tuto metodu je rozlišení mezi pamětí procedurální a deklarativní, které jsou součástí dlouhodobé paměti (Wechsler, 2011). Procedurální pamět' zahrnuje naučené způsoby chování, deklarativní pamět' je schopnost vybavit si konkrétní

\footnotetext{
${ }^{1}$ Katedra psychologie, Fakulta sociálních studií MU, Joštova 10, 60200 Brno

Došlo do redakce 30.11. 2017
} 
informace. Její součástí je epizodická pamět' zaměřená na vzpomínky spojené s určitým kontextem, a právě na tu se zaměřuje WMS-IIIa.

WMS-IIIa vychází ze třetí revize WMS-III vytvořené roku 1997 D. Wechslerem; původní verze byla vydána roku 1945 (Wechsler, 2011). Na základě studií prověřujících jednotlivé subtesty WMS-III (např. Axelrod \& Woodard, 2000; Millis, Malina, Bowers, \& Ricker, 1999; Price, Tulsky, Millis, \& Weiss, 2002) byly do WMS-IIIa zařazeny subtesty Logická pamět' I a II a Obrázky rodiny I a II. Hlavními důvody byly jejich dobré psychometrické vlastnosti, vysoké korelace s indexovými skóry WMS-III a relativní jednoduchost jejich administrace a hodnocení.

V české adaptaci bylo při překladu provedeno několik změn oproti anglické předloze. Ty se týkaly zejména zadání subtestů Logická pamět', v manuálu však chybí vysvětlení, jak český podnětový materiál v podobě př́běhů vznikal. Také obrazový materiál subtestů Obrázky rodiny byl přizpůsoben českému prostředí, autoři však neuvádějí, čeho přesně se změny týkaly.

\section{Administrace, skórování a interpretace}

Metoda je administrována interaktivně a individuálně, a to výhradně formou "tužka-papír". Její administrace trvá 15-20 minut, mezi částmi na bezprostřední a oddálené vybavení je 25-35minutová pauza. Řadí se mezi metody kategorie C, předpokladem jejího použití je tedy akreditované vysokoškolské vzdělání v oboru psychologie. Distributor navíc doporučuje absolvovat odborné zaškolení v práci s metodou, které však není povinné (Dana Černochová, e-mailová komunikace, 1. 3. 2018).

WMS-IIIa obsahuje čtyři subtesty (Logická pamět' I, Obrázky rodiny I, Logická pamět' II a Obrázky rodiny II) hodnotící sluchovou a zrakovou pamět', bezprostřední a oddálené vybavení. Pořadí subtestů je neměnné. V subtestu Logická pamět' I administrátor přečte dva příběhy, které má vyšetřovaná osoba ihned po přečtení každého příběhu co nejpřesněji reprodukovat. Druhý příběh je přečten dvakrát. V subtestu Obrázky rodiny I si má vyšetřovaná osoba zapamatovat čtyři obrázky, které znázorňují sedm členů rodiny v různých situacích (Piknik, Obchodní dům, Zahrada a Oběd). Po zhlédnutí obrázků má identifikovat, které postavy byly na obrázku, $\mathrm{v}$ jaké části se nacházely a jakou činnost vykonávaly. Následuje pauza, po které je osoba vyzvána, aby si vybavila co nejvíce informací $\mathrm{z}$ obou dříve prezentovaných příběhů, stejně jako obsah obrázků podle zmíněných kritérií.

Po zaznamenání a oskórování odpovědí v šabloně lze součtem získat hrubé skóry pro jednotlivé subtesty. U subtestů Logická pamět' I a II se za správné vybavení detailu příběhu uděluje 1 bod, za nevybavení 0 bodů. $V$ subtestech Obrázky rodiny I a II lze obdržet až 4 body za každého správně umístěného člena rodiny a za pojmenování jeho činnosti a předmětu interakce. Tyto hrubé skóry jednotlivých subtestů lze na základě tabulek převést na vážené skóry. Součtem vážených skórů subtestů Logická pamět' I a Obrázky rodiny I vznikne vážený skór Bezprostřední paměti (BP). Součtem vážených 
skórů subtestů Logická pamět' II a Obrázky rodiny II vznikne vážený skór Oddálené paměti (OP). Součtem vážených skórů BP a OP vznikne vážený skór Celkové paměti $(\mathrm{CP})$. Vážené skóry BP, OP a CP lze pomocí českých norem převést na souhrnné standardní IQ skóry (M=100, SD=15) spolu s jejich intervaly spolehlivosti.

Autoři nedoporučují výpočet skórů BP, OP nebo CP v př́ípadě, že analýza diskrepancí v souhrnných skórech a skórech subtestů odhalí statisticky signifikantní rozdíly. Pro tento účel je $\mathrm{v}$ manuálu tabulka kritických hodnot pro posouzení signifikance diskrepancí spolu s návodem k výpočtu. Manuál WMS-IIIa poskytuje také tabulky pro odhad skóru Celkového indexu paměti WMS-III a tabulky pro odhad souhrnného skóru CP na základě Celkového inteligenčního kvocientu (CIQ) získaného ve třetí verzi Wechslerovy inteligenční škály pro dospělé (WAIS-III).

\section{Normy}

Normy byly vytvořeny na české populaci, a to na souboru 490 dobrovolníků ve věku 20-89 let (z toho 305 žen). Z hlediska věku a vzdělání byl soubor sestaven tak, aby co nejlépe reprezentoval českou populaci. Autoři reportují průměrný věk celého souboru $(M=48, S D=17,2)$, žen $(M=50, S D=17,5)$ a mužů $(M=44, S D=16,3)$. Soubor byl rozdělen do 9 věkových skupin. Osm věkových skupin do 74 let kopíruje původní americkou standardizaci, vyšší věkové skupiny nebyly dále diferencovány. Do deváté skupiny byli zařazeni ostatní probandi ve věku 75-89 let. Důvodem byl malý počet probandů vyššího věku v českém standardizačním vzorku. Z hlediska vzdělání se autoři snažili o jeho reprezentativní distribuci dle údajů zveřejněných Českým statistickým úřadem, a to na třech úrovních (základní, střední a vysokoškolské). Ve třech nejvyšších věkových kategoriích (65-69, 70-74 a 75-89 let) autoři vybízejí k opatrnosti při interpretaci skórů, protože v těchto skupinách byl ve standardizačním vzorku menší podíl jedinců se základním vzděláním, než odpovídá české populaci.

Přestože manuál umožňuje transformaci hrubých skórů na standardizované skóry u 9 věkových kategorií, zhodnocení adekvátnosti norem komplikuje nedostatek informací o standardizačním souboru. Autoři neuvádějí bližší informace o probandech v jednotlivých skupinách ani způsob výběru osob do vzorku. Jisté informace může přinést diplomová práce jedné z autorek metody (Jenčová, 2009), ve které byla využita data projektu standardizační studie (A. Jenčová, osobní komunikace, 3. února 2018), tu však manuál neuvádí jako oficiální zdroj. Tato práce například naznačuje, že dobrovolníci byli poprvé kontaktováni většinou prostřednictvím Psychiatrického centra Praha, což mohlo mít za následek nevelkou reprezentativnost vzorku vůči populaci např́íc Českou republikou. Normy se navíc mohou zdát dostatečně velké, reálně však na jednu věkovou kohortu připadá cca 60 osob. Autoři redukovali tento nedostatek prostřednictvím plošné transformace a vyhlazením křivek (D. Černochová, osobní komunikace, 28. března 2018), tato skutečnost však není uvedena v manuálu. 


\section{Reliabilita}

V manuálu metody autoři reportují různé koeficienty reliability. Prvním je split-half reliabilita jednotlivých subtestů, u které však autoři uvedli, že ji na datech k české standardizaci z nezmíněných důvodů nebylo možné spočítat. Namísto toho uvedli hodnoty dosažené $\mathrm{v}$ americké standardizaci $(0,79-0,88)$. Autoři české adaptace v manuálu dále uvádějí Cronbachův koeficient alfa pro souhrnné skóry, který se pohyboval v rozmezí $0,70-0,86$ např́í věkovými skupinami. Tyto hodnoty jsou nižší než v rámci americké standardizační studie, kde koeficienty dosahovaly hodnot 0,87-0,92. Test-retestovou reliabilitu česká standardizační studie neposkytuje, protože nebyla prováděna žádná následná měření. Autoři proto reportují koeficienty získané při americké standardizaci $(0,61-0,80$ pro skóry subtestů, $0,71-0,81$ pro souhrnné skóry). Jako poslední je uveden koeficient shody mezi posuzovateli převzatý z americké standardizace, který dle autorů přesáhl hodnotu 0,90. K hodnocení shody byla provedena skórovací studie, ve které bylo dvakrát nezávisle vyhodnoceno deset protokolů pro každou věkovou skupinu. $\mathrm{V}$ českém manuálu však není uvedeno, který koeficient shody byl pro výpočet zvolen. Česká adaptace navíc používá v subtestech Logická pamět' I a II vlastní př́běhy, drobné jazykové nuance skórování proto nemusí být ošetřené.

Jediným údajem vypovídajícím o české adaptaci testu tedy zůstává Cronbachova alfa. Ta je vypočítána pro souhrnné skóry jednotlivých věkových skupin, pro něž autoři uvádějí standardní chyby měření. Pro výpočet Cronbachovy alfy použili namísto položkových dat souhrnné skóry subtestů, což nutně vede k silnému podhodnocení celkové reliability. Tím lze vysvětlit také to, proč je reliabilita nižší ve srovnání s americkou standardizační studií. Manuál pak sice poskytuje přehlednou tabulku intervalů spolehlivosti pro výsledky v jednotlivých věkových skupinách, tyto hodnoty však vyplývají z nevhodného způsobu výpočtu reliability.

Za hlavní slabiny hodnocení reliability lze považovat nezdůvodňování, chybějící informace a postup, jakým byla vypočítána. Protože je česká adaptace WMS-IIIa strukturována stejně jako originální verze, lze údaje o reliabilitě originálu vnímat jako orientační. Reliabilitu české adaptace však nelze adekvátně posoudit, je třeba dalších návazných studií.

\section{Validita}

Veškeré informace o validitě WMS-IIIa autoři adaptace přejímají z originální americké standardizační studie, která podává celou řadu důkazů o validitě metody. Tyto údaje však nutně neznamenají, že validita je podobná u české verze metody, a to zejména kvůli úpravám provedeným na české adaptaci. Jak sami autoři uvádějí, ověření validity na české populaci by mělo být předmětem dalšího výzkumu. Následující informace o validitě metody je tedy třeba opět považovat za orientační.

Wechsler (2011) při vydání třetí verze Wechslerovy pamět'ové škály spolu s její zkrácenou verzí publikoval sérii validizačních studií provedených v rámci americké 
standardizace. Ty se věnují souběžné, diskriminační, kriteriální a konstruktové validitě. Klinicky významný rozdíl mezi obtížností plné a zkrácené verze nalezen nebyl, souhrnné skóry WMS-IIIa by tedy měly odrážet WMS-III. WMS-IIIa vysoce koreluje s jinými nástroji měření paměti. Vysoká korelace je uvedena např. pro MMSE a škály paměti a pozornosti v rámci Mattisovy škály demence. Naopak nízké korelace se ukázaly v souvislosti s expresí jazyka, ačkoliv je výkon WMS-IIIa zprostředkován verbálními schopnostmi.

Vzhledem k tomu, že WMS-IIIa je navržena k měření deklarativní paměti, předpokládala se její vysoká senzitivita na poruchy spojené s amnézií a demencí. Testovaly se proto rozdíly mezi různými klinickými skupinami (např. pacienti s Alzheimerovou chorobou, Parkinsonovou chorobou, roztroušenou sklerózou aj.). Zkrácená verze byla autory vyhodnocena jako senzitivní na různě závažná poškození paměti s tím, že však neumožňuje - a ani si neklade za cíl - rozlišení deficitů sluchové či zrakové paměti.

Faktorová validita byla testována pouze na nezkrácené verzi WMS-III, a to na zahraničních verzích (Millis et al., 1999; Price et al., 2002). Jejím smyslem byla volba subtestů k použití do zkrácené verze, lze ji ale zřejmě zobecnit i na WMS-IIIa.

Další informace opět přináší diplomová práce jedné z autorek metody (Jenčová, 2009), ve které byla testována kriteriální validita jako souvislost mezi WMS-IIIa a dalšími metodami, např. Pamětovým testem učení (AVLT), Číselnými řadami ISA či Testem cesty (TMT). Korelační analýza ukázala středně silné vztahy, tyto hodnoty je ale také třeba považovat za orientační vzhledem k omezenému souboru (respondenti ve věku 20-39 let).

\section{Závěr}

Českou adaptaci této rozšířené pamět'ové škály lze těžko ohodnotit, a to primárně z důvodu nedostatku informací. Jediných ukazatelem reliability, který byl na české adaptaci posouzen, byla vnitřní konzistence testu, jejíž způsob výpočtu pravděpodobně zapříčinil snížení její hodnoty oproti původní americké standardizační studii. Další ukazatele, např. test-retestová realibilita, split-half reliabilita jednotlivých subtestů a shoda posuzovatelů, nebyly na české adaptaci testovány. Zejména chybějící informace o shodě posuzovatelů se mohou ukázat jako problematické, a to kvůli změnám v překladu oproti původní anglické verzi.

Další nedostatek spatřujeme $\mathrm{v}$ absenci ověření validity české adaptace testu. Český uživatel testu by si měl být vědom, že informace uvedené v manuálu vyplývají pouze z americké standardizace, což automaticky neimplikuje stejné fungování testu na české populaci. Je také nutno dodat, že zhodnocení norem vytvořených na české populaci je ztíženo chybějícími informacemi o standardizačním souboru a způsobu jeho výběru. Nyní dostupné informace tak poukazují na nedostatečnost českých norem.

Oceňujeme však překlad a kvalitu testových materiálů. Položky a instrukce metody WMS-IIIa jsou jasné a srozumitelné, popis administrace včetně skórování a interpretace 
testu je podrobný. Pozornost by se měla přesunout k funkčnosti WMS-IIIa v českém prostředí a k podrobnému testování jejích psychometrických vlastností. WMS-IIIa by se dala označit za metodu s velkým potenciálem, na což poukazují psychometrické vlastnosti původní anglické verze. Velkou slabinu české verze WMS-IIIa tedy nevidíme v metodě samotné, ale $\mathrm{v}$ české standardizační studii a nedůsledné psychometrické analýze.

V literatuře je větší prostor věnován nezkráceným verzím Wechslerových pamět’ových šál (viz Kent, 2013), doporučovaly bychom proto její další testování a vývoj. Je možné tuto metodu použít expertním uživatelem za pečlivě kontrolovaných podmínek nebo ve velmi omezených aplikačních oblastech za předpokladu, že uživatel testu bude obezřetný v interpretaci výsledků.

\section{Zdroje}

Axelrod, B. N., \& Woodard, J. L. (2000). Parsimonious prediction of Wechsler Memory Scale-III Memory Indices. Psychological Assessment, 12(4), 431-435.

Jenčová, A. (2009). Wechslerova pamětová škála-třetí vydání, zkrácená verze. Retrieved from dspace.cuni.cz.

Kent, P. (2013). The evolution of the Wechsler Memory Scale: A selective review. Applied Neuropsychology: Adult, 20(4), 277-291.

Millis, S. R., Malina, A. C., Bowers, D. A., \& Ricker, J. H. (1999). Confirmatory factor analysis of the Wechsler Memory Scale-III. Journal of Clinical and Experimental Neuropsychology, 21(1), 8793.

Price, L. R., Tulsky, D., Millis, S., \& Weiss, L. (2002). Redefining the factor structure of the Wechsler Memory Scale-III: Confirmatory factor analysis with cross-validation. Journal of Clinical and Experimental Neuropsychology, 24(5), 574-585.

Wechsler, D. (2011). Wechslerova zkrácená pamět'ová škála WMS-IIIa. Praha: Hogrefe Testcentrum. 


\section{MODEL RECENZE PODLE EFPA PRO POPIS \\ A HODNOCENÍ PSYCHOLOGICKÝCH TESTŮ \\ FORMULÁŘ RECENZE TESTU A POZNÁMKY PRO \\ RECENZENTY ${ }^{1}$}

Toto je lokální úprava dokumentu pro účely publikace v časopise Testfórum.

Originální český překlad je k dispozici na stránkách EFPA

(www.efpa.eu/download/505cd9db4144ecb16174087909c9cd6d).

Původní verzi sestavil a uspořádal Dave Bartram

Doplnili a revidovali Patricia Lindley, Dave Bartram a Natalie Kennedy v dubnu $2004^{2}$

Současná verze 3.42: květen 2005

Český překlad: Tomáš Urbánek

Od uživatelů tohoto dokumentu a jeho obsahu žádá EFPA, aby uznali tento zdroj prostřednictvím následujícího textu:

"Kritéria pro recenzi testu podle EFPA do značné míry vychází z formy a obsahu kritérií pro recenze testů Britské psychologické společnosti (BPS) a kritérií vytvořených Komisí pro testové záležitosti (COTAN) Holandské asociace psychologů (NIP). Dave Bartram a Patricia Lindley pưvodně vyvinuli kritéria BPS a recenzní procedury pro UK Employment Service a později rozšírili jejich používání pro celou BPS. Arne Evers připravil k vydání nizozemský system posuzování kvality testů.

EFPA je vděčná BPS a NIP za svolení použít jejich kritéria jako základ pro vytvoření evropského modelu. EFPA je také vděčná Davu Bartramovi, Arnu Eversovi a Patricii Lindley za jejich přispění $k$ vývoji tohoto modelu. Veškerá intelektuální vlastnická práva původních kritérií podle BPS a NIP jsou nadále uznávána a náleží těmto orgánům."

\footnotetext{
1 Tento dokument byl vytvořen z několika zdrojů, včetně Hodnotícího formuláře pro recenzi testu používaného v BPS (NPAL a Řídící komise pro testové standardy při BPS - Steering Committee on Test Standards), Španělského dotazníku pro hodnocení psychometrických testů (Španělská psychologická asociace) a Systému pro posuzování kvality testu (Komise pro testování Holandské asociace psychologů). Některé části byly adaptovány se svolením z dokumentu: BPS Books Reviews of Level B Assessment Instruments for use in Occupational Assessment, Notes for Reviewers: Version 3.1. December 1998: Copyright (C) NPAL, 1989, 1993, 1998.

${ }^{2}$ Současná verze je spojením dvou oddělených dokumentů (Formuláře recenze a Poznámek pro recenzenty). Obsah byl navíc uspořádán a doplněn na základě jeho používání recenzenty online testů v BPS.
} 


\section{Část 1:}

Popis nástroje: Obecné informace a klasifikace

\begin{tabular}{|c|c|c|}
\hline \multicolumn{3}{|c|}{ EFPA 3.2 reference } \\
\hline & Recenzent 1: & Bc. Renata Hlavová \\
\hline & Recenzent 2: & Bc. Anna Marie Rosická \\
\hline & Konzultující editor: & Mgr. Hynek Cígler, Ph.D. \\
\hline & Vedoucí editor: & Mgr. Hynek Cígler, Ph.D. \\
\hline & $\begin{array}{l}\text { Vedoucí editor aktualizace: } \\
\text { (pouze v prrípadě aktualizací) }\end{array}$ & zástupce Testfóra (nevyplňujte) \\
\hline & $\begin{array}{l}\text { Editor aktualizace: } \\
\text { (pouze v př́ípadě aktualizací) }\end{array}$ & zástupce Testfóra (nevyplňujte) \\
\hline & Datum vzniku této recenze: & 30.11 .2017 \\
\hline \multirow[t]{2}{*}{1.1} & Název nástroje (lokální verze): & Wechslerova zkrácená pamět’ová škála \\
\hline & Zkrácená verze názvu testu: & WMS-IIIa \\
\hline 1.2 & $\begin{array}{l}\text { Původní název testu (pokud je lokální } \\
\text { verze adaptací): }\end{array}$ & $\begin{array}{l}\text { Wechsler Memory Scale - Third Edition } \\
\text { Abbreviated }\end{array}$ \\
\hline 1.4 & Autoři původního testu: & David Wechsler \\
\hline 1.3 & Autoři lokální adaptace: & Adéla Jenčová, Dana Černochová \\
\hline 1.7 & Lokální distributor/vydavatel testu: & Hogrefe - Testcentrum \\
\hline 1.8 & $\begin{array}{l}\text { Vydavatel původní verze testu (pokud je } \\
\text { jiný než současný distributor/vydavatel): }\end{array}$ & Nakladatelství Pearson \\
\hline 1.9.1 & Datum vydání současné revize/vydání: & 1997 \\
\hline 1.9 .2 & $\begin{array}{l}\text { Datum vydání adaptace pro lokální } \\
\text { užívání: }\end{array}$ & 2011 \\
\hline 1.9 .3 & Datum vydání původního testu: & 1945 \\
\hline
\end{tabular}




\section{Obecný popis nástroje}

Předmětem této recenze je česká adaptace Wechslerovy zkrácené pamět'ové škály ( $\mathrm{v}$ originále Wechsler Memory Scale - Third Edition Abbreviated; dále jen WMS-IIIa). Jedná se o zkrácenou verzi třetí revize Wechslerovy pamětové škály (WMS-III) od D. Wechslera z roku 1997, která měří deklarativní epizodickou pamět'. Je určena pro populaci ve věku 20-89 let a zjišt'uje fungování sluchové a zrakové paměti, a to $\mathrm{z}$ hlediska bezprostředního a oddáleného vybavení.

WMS-IIIa je zaměřena na orientační měření aktuálního fungování paměti. Dle autorů je metoda využitelná především v klinické praxi, a to pro screeningovou diagnostiku narušení paměti či jako součást komplexního psychologického nebo neuropsychologického vyšetření.

Metoda je administrována interaktivně a individuálně, a to výhradně ve formě "tužka-papír". Její administrace trvá 15-20 minut, mezi částmi na bezprostřední a oddálené vybavení je 25-35minutová pauza. Řadí se mezi metody kategorie $\mathrm{C}$ i přesto, že odborné zaškolení v práci s metodou je distributorem pouze doporučené, tj. nepovinné.

WMS-IIIa obsahuje 4 subtesty hodnotící sluchovou a zrakovou pamět', bezprostřední a oddálené vybavení. Subtesty jsou následující: (i) Logická pamět' I, (ii) Obrázky rodiny I, (iii) Logická pamět’ II a (iv) Obrázky rodiny II. Pořadí subtestů je neměnné. V subtestu Logická pamět' I administrátor přečte př́běh, který má vyšetřovaná osoba co nejpřesněji reprodukovat. Druhý př́běh je osobě přečten dvakrát. Vyšetřovaná osoba reprodukuje obsahy příběhů ihned po přečtení každého př́běhu. $V$ subtestu Obrázky rodiny I si má vyšetřovaná osoba zapamatovat čtyři obrázky, které znázorňují různé členy rodiny na následujících místech: Piknik, Obchodní dům, Zahrada a Oběd. Po zhlédnutí všech obrázků má identifikovat, které osoby byly na obrázku, v jaké části obrázku se nacházely a kterou činnost vykonávaly. Po pauze je osoba vyzvána, aby si vybavila co nejvíce informací z obou dříve prezentovaných př́běhů, stejně jako obsah obrázků podle zmíněných kritérií.

Po zaznamenání a oskórování odpovědí v šabloně lze jednoduchým součtem vypočítat hrubé skóry pro všechny 4 subtesty. Tyto hrubé skóry lze na základě tabulek převést na vážené skóry jednotlivých subtestů. Vážené skóry BP, OP a CP lze pomocí českých norem převést na celkové standardní IQ skóry $(\mathrm{M}=100, \mathrm{SD}=15)$ spolu s jejich intervaly spolehlivosti. 


\section{Část 2:}

\section{Klasifikace}

\begin{tabular}{|c|c|c|}
\hline 1.10 .1 & Obsahová doména & $\begin{array}{ll} & \text { Školní schopnosti } \\
\square & \text { Všeobecné schopnosti } \\
\square & \text { Verbální schopnosti } \\
\square & \text { Numerické schopnosti } \\
\square & \text { Prostorové schopnosti } \\
\square & \text { Neverbální schopnosti } \\
\square & \text { Rychlost vnímání } \\
\otimes & \text { Pamět' } \\
\square & \text { Manuální zručnost } \\
\square & \text { Osobnost - Rys } \\
\square & \text { Osobnost - Typ } \\
\square & \text { Osobnost - Stav } \\
\square & \text { Kognitivní styly } \\
\square & \text { Motivace } \\
\square & \text { Hodnoty } \\
\square & \text { Zájmy } \\
\square & \text { Přesvědčení } \\
\square & \text { Poruchy a patologie } \\
\square & \text { Skupinové procesy } \\
\square & \text { Rodina } \\
\square & \text { Organizace, její fungování, agregovaná } \\
\text { měření, klima atd. } \\
\square \text { Školní nebo výchovné funkce } \\
\square \text { Jiné: }\end{array}$ \\
\hline 1.10 .2 & $\begin{array}{l}\text { Zamýšlená(é) nebo hlavní oblast(i) } \\
\text { použití. }\end{array}$ & $\begin{array}{ll} & \text { Klinická psychologie } \\
\otimes & \text { Neuropsychologie } \\
\square & \text { Forenzní psychologie } \\
\square & \text { Psychologie výchovy a vzdělávání } \\
\square & \text { Psychologie práce a personalistika } \\
\square & \text { Poradenství, doporučení, vedení a volba } \\
& \text { povolání } \\
\square & \text { Psychologie zdraví, životní styl a životní } \\
& \text { spokojenost } \\
\square & \text { Sporty a volný čas } \\
\square & \text { Jiné: }\end{array}$ \\
\hline
\end{tabular}




\begin{tabular}{|c|c|c|}
\hline 1.10 .3 & $\begin{array}{l}\text { Zamýšlený způsob použití } \\
\text { (podmínky, za jakých byl nástroj } \\
\text { standardizován a validizován) }\end{array}$ & $\begin{array}{l}\square \text { Nesupervidovaná administrace bez } \\
\text { kontroly nad identitou respondenta a bez } \\
\text { úplné kontroly nad podmínkami } \\
\text { administrace (např. volně přístupný test } \\
\text { na internetu, test dostupný ke koupi v } \\
\text { knihkupectví). } \\
\square \text { Kontrolovaný nesupervidovanou } \\
\text { administrcí. Kontrola nad podmínkami } \\
\text { (čas atd.) a určitá kontrola nad identitou } \\
\text { uživatele testu (např. testy } \\
\text { administrované přes internet, ale pouze } \\
\text { známým osobám - př́istup omezený } \\
\text { heslem). } \\
\text { Supervidovaná a kontrolovaná } \\
\text { administrace. Administrace testu pod } \\
\text { kontrolou kvalifikovaného adminitrátora } \\
\text { nebo dohlížitele. } \\
\text { Řízená administrace. Administrace testu } \\
\text { prováděná pouze přes určená testovací } \\
\text { centra (např. programy hodnocení licencí } \\
\text { a certifikace). }\end{array}$ \\
\hline 1.10 .4 & $\begin{array}{l}\text { Popis populací, pro které je test } \\
\text { určen: }\end{array}$ & $\begin{array}{l}\text { Metoda je určena pro muže a ženy od } 20 \text { do } \\
89 \text { let. Vydavatelé vybízí k opatrnosti při } \\
\text { interpretaci skórů pro tři nejvyšší věkové } \\
\text { kategorie (65-69, 70-74 a 75-89 let), ve } \\
\text { kterých nebyl standardizační vzorek } \\
\text { reprezentativní z hlediska vzdělání vzhledem } \\
\text { k české populaci. }\end{array}$ \\
\hline 1.10 .5 & $\begin{array}{l}\text { Počet škál a krátký popis } \\
\text { proměnné nebo proměnných } \\
\text { měřených nástrojem }\end{array}$ & $\begin{array}{l}\text { Získané hodnoty lze interpretovat z hlediska } \\
\text { tří kompozitních skórù. } \\
\text { Souhrnný skór bezprostřední paměti měří, } \\
\text { nakolik je vyšetřovaná osoba schopna vybavit } \\
\text { si informace hned poté, co jí byly } \\
\text { prezentovány. } \\
\text { Souhrnný skór oddálené paměti odráží } \\
\text { schopnost vybavit si dříve prezentované } \\
\text { informace po uplynutí určitého časového } \\
\text { úseku. } \\
\text { Souhrnný skór celkové paměti je odhadem } \\
\text { aktuálního fungování paméti vyšetřované } \\
\text { osoby. Obsahuje elementy procesủ zrakové a } \\
\text { sluchové paměti, bezprostředního a } \\
\text { oddáleného vybavení. }\end{array}$ \\
\hline
\end{tabular}




\begin{tabular}{|c|c|c|}
\hline 1.11 & Formát položek & $\begin{array}{ll} & \text { Otevřený } \\
\bigotimes & \text { Mnohonásobná volba, alternativy na } \\
& \text { stejné škále } \\
\square & \text { Bipolární adjektiva } \\
\square & \text { Likertovy ratingy (škály) } \\
\square & \text { Nucená volba, alternativy na smíšených } \\
\text { škálách (ipsativní) - vysvětlení viz } \\
\text { Poznámky } \\
\square \\
\text { Mnohonásobná volba, alternativy na } \\
\text { smíšených škálách (ipsativní) - } \\
\text { vysvětlení viz Poznámky } \\
\square \text { Sady párů adjektiv (sémantický } \\
\text { diferenciál), smíšené škály (ipsativní) } \\
\square \text { Jiné: }\end{array}$ \\
\hline 1.12 & Počet položek testu: & $\begin{array}{l}\text { WMS-IIIa má celkem } 157 \text { položek. } \\
\text { Subtest Logická pamět' I obsahuje } 75 \text { položek, } \\
\text { Logická pamět' II } 50 \text { položek. } \\
\text { U subtestů Obrázky rodiny I a II nebylo } \\
\text { specifikováno, co se za položku považuje. } \\
\text { Protože autoři kalkulují s jednotlivými skóry } \\
\text { postav, budou se za položky považovat } \\
\text { jednotlivé postavy. Subtest Obrázky rodiny I } \\
\text { tak má } 16 \text { položek stejně jako subtest Obrázky } \\
\text { rodiny II. }\end{array}$ \\
\hline 1.13 & Způsob(y) administrace: & $\begin{array}{ll}\bigotimes & \text { Interaktivní individuální administrace } \\
\square & \text { Supervidovaná skupinová administrace } \\
\square & \text { Počítačová lokálně nainstalovaná } \\
\text { aplikace - pod supervizí/dohledem } \\
\square \quad \text { Počítačová aplikace na webu - pod } \\
\text { supervizí/dohledem } \\
\square \\
\text { Počítačová lokálně nainstalovaná } \\
\text { aplikace - bez supervise/testování sebe } \\
\square \quad \text { Počítačová aplikace na webu - bez } \\
\text { supervize/testování sebe } \\
\square \text { Jiné: }\end{array}$ \\
\hline 1.14 & Způsob odpovídání: & $\begin{array}{ll}\bigotimes & \text { Ústní rozhovor } \\
\square & \text { Papír a tužka } \\
\square & \text { Manuální operace } \\
\square & \text { Na počítači } \\
\square & \text { Jiné: }\end{array}$ \\
\hline
\end{tabular}




\begin{tabular}{|c|c|c|c|}
\hline 1.15 & 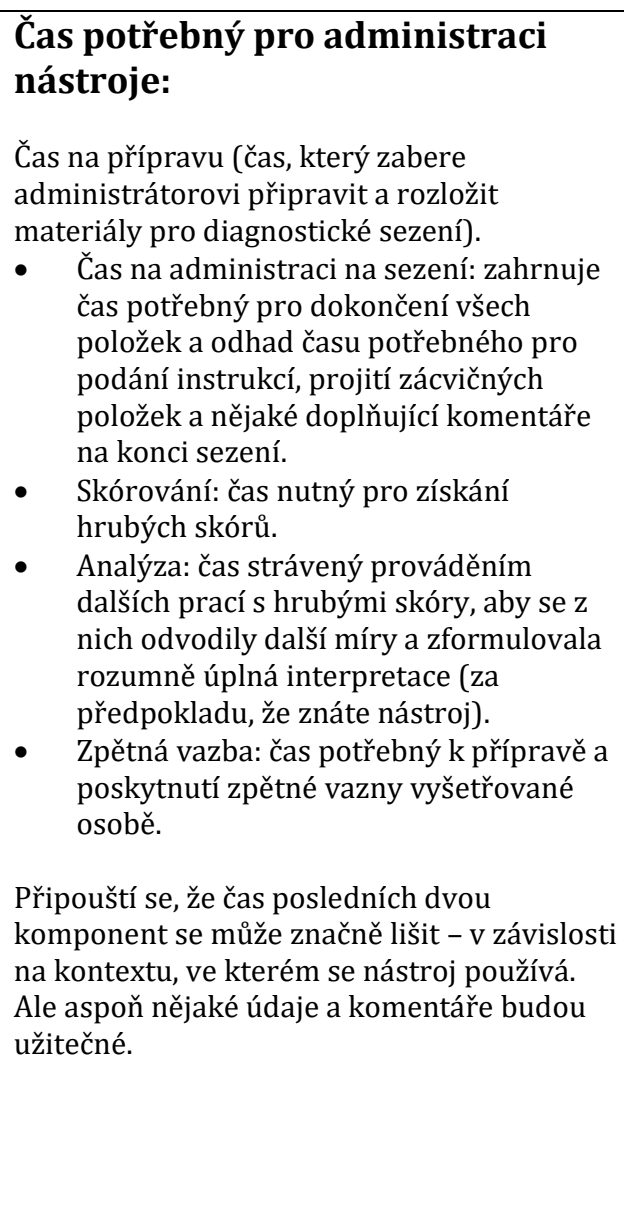 & $\begin{array}{l}\text { Skórování: } \\
\text { Analýza: } \\
\text { Zpětná vazba: } \\
\text { Manuál uvádí } \\
\text { k samotné adm } \\
\text { přípravy, trván } \\
\text { zpětné vazby jo } \\
\text { osobní zkušen } \\
\text { s metodou. } \\
\text { Vzhledem k tor } \\
\text { screeningová a } \\
\text { oblastech pam } \\
\text { považujeme za } \\
15 \text { minut a dob }\end{array}$ & $\begin{array}{l}5 \text { minut } \\
\text { 15-20 minut čistého } \\
\text { času, mezi částmi na } \\
\text { bezprostřední a } \\
\text { oddálené vybavení je } \\
\text { 25-35minutová pauza } \\
20 \text { minut } \\
15 \text { minut } \\
10 \text { minut } \\
\text { ouze čas potřebný } \\
\text { inistraci. Údaje o době } \\
\text { skórování, analýzy a } \\
\text { ou odhadnuty na základě } \\
\text { sti recenzentek }\end{array}$ \\
\hline 1.16 & $\begin{array}{l}\text { Jsou k dispozici různé formy } \\
\text { nástroje? }\end{array}$ & $\begin{array}{l}\text { Předmětem tét } \\
\text { papír“, která je } \\
\text { verzi z roku } 20 \\
\text { metody neexist } \\
\text { WMS-IIIa je zkr } \\
\text { III a zahrnuje ce } \\
\text { z původních } 17\end{array}$ & $\begin{array}{l}\text { recenze je forma „tužka- } \\
\text { současnosti k dostání ve } \\
\text { 1. Počítačová verze } \\
\text { ije. } \\
\text { acenou verzí testu WMS- } \\
\text { lkem } 4 \text { subtesty }\end{array}$ \\
\hline
\end{tabular}

\section{Část 3:}

\section{Měření a skórování}

\begin{tabular}{|c|c|c|}
\hline 1.17 & Procedura skórování testu: & 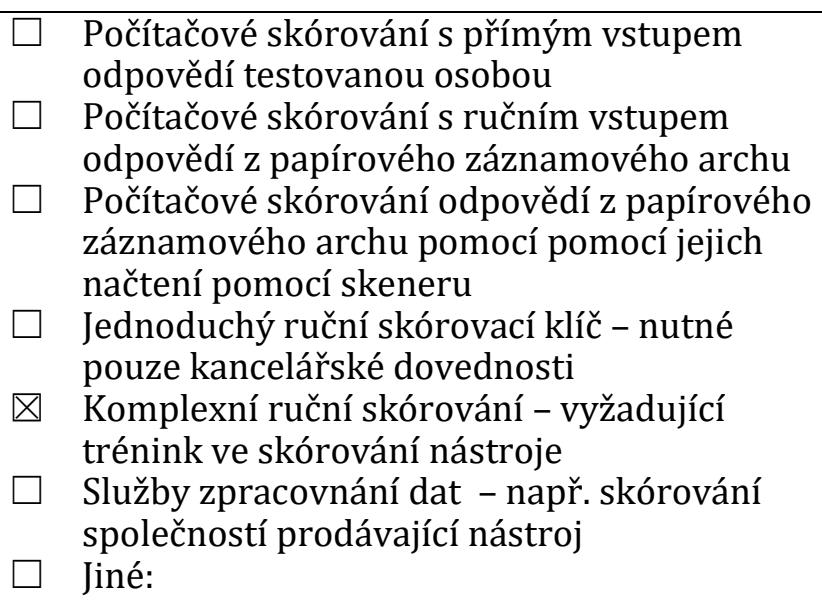 \\
\hline
\end{tabular}




\begin{tabular}{|c|c|c|}
\hline 1.18 & Skóry: & $\begin{array}{l}\text { Po zaznamenání a oskórování odpovědí v šabloně } \\
\text { lze jednoduchým součtem vypočítat hrubé skóry } \\
\text { pro všechny } 4 \text { subtesty. Za správnou odpověd' se } \\
\text { získává } 1 \text { bod, za špatnou } 0 \text { bodů v případě } \\
\text { subtestů Logická pamět' I a II, v případě subtestů } \\
\text { Obrázky rodiny I a II lze za přesnou odpověd' } \\
\text { ohodnotit i } 2 \text { body. } \\
\text { Tyto hrubé skóry lze na základě tabulek převést } \\
\text { na vážené skóry jednotlivých subtestů. Součtem } \\
\text { vážených skórủ subtestů Logická pamět' I a } \\
\text { Obrázky rodiny I vznikne vážený skór } \\
\text { Bezprostřední paměti (BP). Součtem vážených } \\
\text { skórů subtestů Logická pamét' II a Obrázky } \\
\text { rodiny II vznikne vážený skór Oddálené paměti } \\
\text { (OP). Součtem vážených skórů BP a OP vznikne } \\
\text { vážený skór Celkové paměti (CP). Výpočet } \\
\text { žádného ze souhrnných skórů (BP, OP a CP) se } \\
\text { nedoporučuje v př́padě, že analýza diskrepancí } \\
\text { v souhrnných skórech a skórech subtestů odhalí } \\
\text { statisticky signifikantní rozdíly. } \\
\text { Vážené skóry BP, OP a CP lze na základě českých } \\
\text { norem převést na standardní skóry (M=100, } \\
\text { SD=15) spolu s jejich intervaly spolehlivosti. Na } \\
\text { základě tabulek lze také odhadnout odhadovaný } \\
\text { skór Celkového indexu paměti WMS-III. } \\
\text { Výsledky v podobě skórů subtestů a souhrnných } \\
\text { skórů lze zakreslit do testového profilu } \\
\text { probanda. }\end{array}$ \\
\hline 1.19 & $\begin{array}{l}\text { Transformace skóru na standardní } \\
\text { skóry: }\end{array}$ & $\begin{array}{ll}\bigotimes & \text { Normalizovaná - skóry se získají použitím } \\
\text { normalizační tabulky } \\
\square \\
\text { Nenormalizovaná - skóry se získají lineární } \\
\text { transformací }\end{array}$ \\
\hline 1.20 & Použité škály & 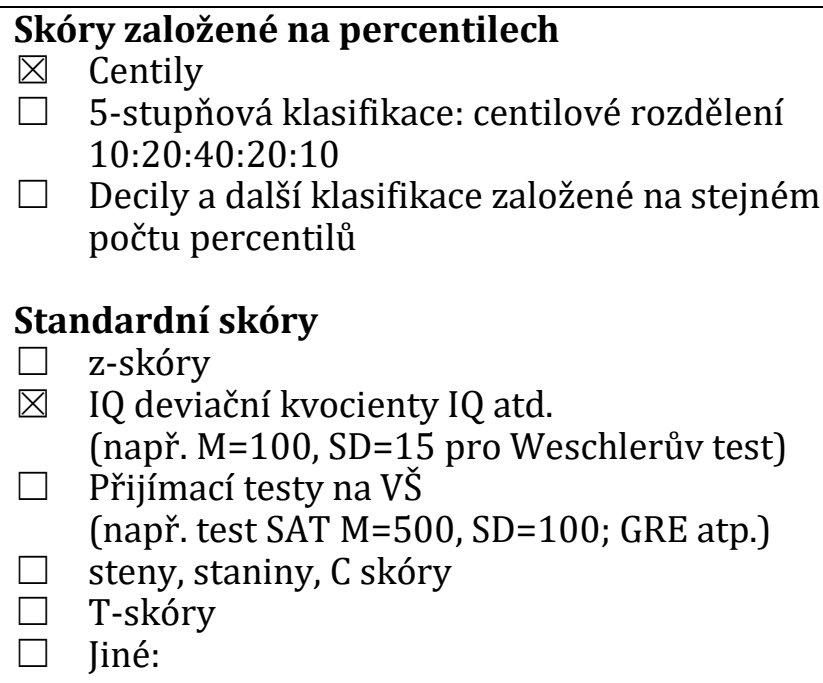 \\
\hline
\end{tabular}




\section{Část 4:}

\section{Počítačově generované zprávy}

Toto je čistě popisné. Hodnocení zpráv bude součástí části recenze nazvané Hodnocení.

\begin{tabular}{|l|l|ll|}
\hline 1.21 & $\begin{array}{l}\text { Jsou počítačově generované zprávy } \mathbf{k} \\
\text { dispozici s nástrojem? }\end{array}$ & $\square \quad$ Ano \\
& $\bigotimes \quad \mathrm{Ne}$ \\
\hline
\end{tabular}

\section{Část 5:}

\section{Nabídka, podmínky a náklady}

Tato část definuje, co vydavatel poskytne, komu, za jakých podmínek a za jaké ceny. Definuje podmínky kladené dodavatelem a týkající se toho, kdo smí a kdo nesmí získat materiál nástroje. Pokud jedna z možností neodpovídá podmínkám nabídky, doplňte popis relevantních podmínek.

\begin{tabular}{|c|c|c|}
\hline 1.23 & $\begin{array}{l}\text { Dokumentace poskytovaná } \\
\text { distributorem jako součást } \\
\text { testového balíku }\end{array}$ & 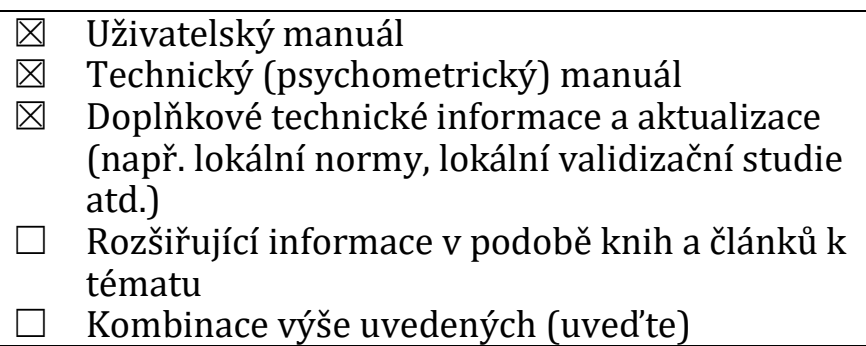 \\
\hline 1.24 & Metody publikace & $\begin{array}{ll}\otimes & \text { Papír } \\
\square & \text { PC - Diskety } \\
\square & \text { PC - CD/ROM } \\
\square & \text { Download z internetu } \\
\square & \text { Živý internet (nástroj pracuje v internetovém } \\
& \text { prohlížeči) } \\
\square & \text { Jiné: }\end{array}$ \\
\hline 1.25 .1 & $\begin{array}{l}\text { Počáteční náklady. } \\
\text { Cena kompletní sady materiálů (všechny manuály a } \\
\text { další material nutný k aspon̆ jedné zkušební } \\
\text { administraci). Kolik uchazečúu lze vyšetřovat pomocí } \\
\text { materiálúu získaných za počáteční náklady, kde tyto } \\
\text { náklady zahrnují materially pro opakované vyšetření. }\end{array}$ & $\begin{array}{l}\text { Úplný testový soubor: } 5750 \text { Kč } \\
\text { (příručka, podnětový sešit, } 25 \text { ks záznamových } \\
\text { listů) } \\
\text { Příručka: } 1950 \text { Kč } \\
\text { Podnětový sešit: } 2950 \text { Kč } \\
\text { Záznamový list ( } 25 \text { ks): } 950 \text { Kč } \\
\text { K ceně objednaného zboží se připočítává poštovné a } \\
\text { balné (v ČR ve výši } 180 \text { Kč, na Slovensko ve výši } 490 \\
\text { Kč). }\end{array}$ \\
\hline 1.25 .2 & Opakující se náklady: & $\begin{array}{l}\text { Pro otestování } 25 \text { respondentů ( } 25 \text { ks záznamových } \\
\text { listů): } 950 \text { Kč }\end{array}$ \\
\hline 1.26 .1 & $\begin{array}{l}\text { Ceny za zprávy generované } \\
\text { softwarem nainstalovaným } \\
\text { uživatelem: }\end{array}$ & \\
\hline
\end{tabular}




\begin{tabular}{|c|c|c|}
\hline 1.26 .2 & $\begin{array}{l}\text { Ceny za vyhotovení zprávy zaslené } \\
\text { prostřednictvím pošty/faxu: }\end{array}$ & \\
\hline 1.26 .3 & $\begin{array}{l}\text { Ceny za vyhotovení zprávy zaslené } \\
\text { prostřednictvím internetové služby: }\end{array}$ & \\
\hline 1.27 & $\begin{array}{l}\text { Ceny za další služby a zpracování } \\
\text { dat: opravy nebo vývoj } \\
\text { automatických zpráv: }\end{array}$ & \\
\hline 1.28 & 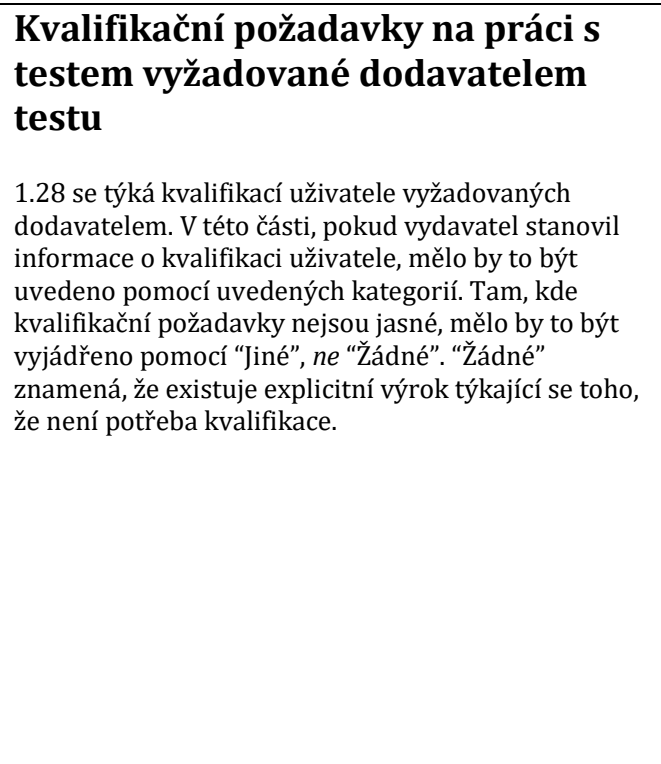 & 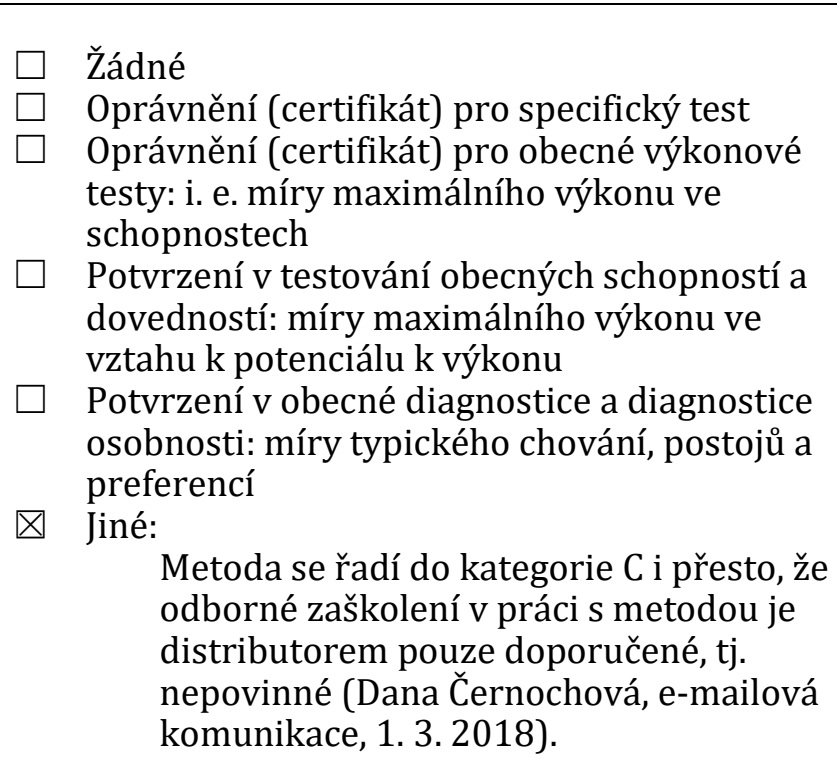 \\
\hline 1.29 & 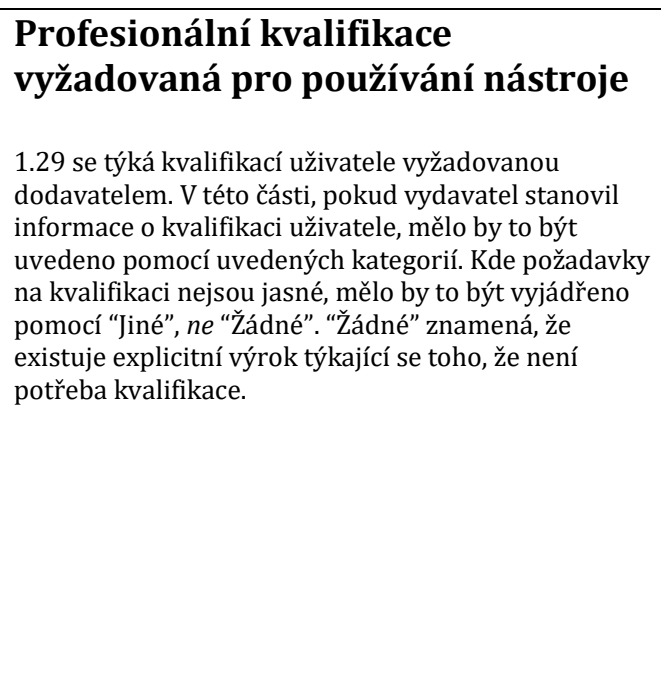 & $\begin{array}{ll} & \text { Žádné } \\
\square & \text { Praktický psycholog s kvalifikací v relevantní } \\
& \text { aplikační oblasti } \\
\square & \text { Praktický psycholog } \\
\square & \text { Výzkumný psycholog } \\
\square & \text { Nepsychologický akademický výzkumník } \\
\square & \text { Praktik v relevantních příbuzných profesích } \\
\text { (terapie, medicína, poradenství, vzdělání, } \\
\text { lidské zdroje atd.) } \\
\square \quad \text { Držitel Certifikátu způsobilosti pro testování } \\
\text { v psychologii práce A BPS } \\
\square \quad \text { Držitel Certifikátu způsobilosti pro testování } \\
\text { v oblastni vzdělávacím A BPS } \\
\square \quad \text { Držitel Certifikátu způsobilosti pro testování } \\
\text { v psychologii práce B BPS } \\
\square \quad \text { Jiné: }\end{array}$ \\
\hline
\end{tabular}


Č́st 6:

Hodnocení testových materiálů

\section{Vysvětlení hodnocení}

V následujících částech jsou celková posouzení adekvátnosti informací týkajících se validity, reliability a norem zobrazeny automaticky tučně.

Jakýkoli nástroj s jedním nebo více posouzeními 0 nebo 2 týkajícími se atributů považovaných za kritické pro bezpečné používání nástroje, by neměl být považován za nástroj, který splňuje minimální standardy.

\begin{tabular}{|c|c|c|c|}
\hline $\begin{array}{c}\text { Vstup na posuzovacím } \\
\text { formulárí }\end{array}$ & $\begin{array}{l}\text { Posouzení podle } \\
\text { standardü EFPA }\end{array}$ & $\begin{array}{c}\text { Reprezentace recenze } v \\
U K\end{array}$ & Vysvětlení \\
\hline [n/a] & {$[\mathrm{n} / \mathrm{a}]$} & [n/a ] & $\begin{array}{l}\text { Tento atribut není u tohoto } \\
\text { nástroje použitelný }\end{array}$ \\
\hline $\mathbf{0}$ & {$[-]$} & [None ] & $\begin{array}{c}\text { Není možné posoudit jako } \\
\text { ne nebo nedostatek } \\
\text { poskytnutých informací }\end{array}$ \\
\hline 1 & {$[-1]$} & {$\left[\begin{array}{ll}* & ]\end{array}\right.$} & Neadekvátní \\
\hline 2 & & {$\left[\begin{array}{ll}* * & ]\end{array}\right.$} & NYNÍ NEPOUŽÍVÁNO \\
\hline 3 & {$\left[\begin{array}{ll}0 & 0\end{array}\right]$} & {$[* * *]$} & Adekvátní nebo přiměřený \\
\hline 4 & [ 1 ] & {$[* * * *]$} & Dobrý \\
\hline \multirow[t]{2}{*}{5} & [ 2 ] & {$[* * * * *]$} & Vynikající \\
\hline & & $\begin{array}{c}\text { [N.r.i.o.r] }{ }^{*} \text { (pouze pro } \\
\text { aktualizace) }\end{array}$ & $\begin{array}{l}\text { Položka nebyla v původní } \\
\text { recenzi posuzována }\end{array}$ \\
\hline
\end{tabular}

V této části má být provedeno více hodnocení různých aspektů nebo atributů dokumentace dodávané s nástrojem (nebo balíkem). Termín „dokumentace“ byl vybrán, aby pokrýval všechny ty materiály dodávané s nástrojem nebo snadno dostupné kvalifikovanému uživateli: např. manual administrátora; technické př́ručky; brožury s normami; dodatky k manuálu; aktualizace od vydavatelů/dodavatelů atd.

Položky mají být posuzovány n/a nebo 0 až 5 (poloviční rating je přijatelný)

Rating

\begin{tabular}{|c|c|c|}
\hline \multicolumn{2}{|r|}{$\begin{array}{l}\text { Kvalita vysvětlení principů, prezentace a kvalita poskytnuté informace: } \\
\text { (Tento celkový rating se získá použitím posouzení založeného na ratinzích daných pro položky } 2.1-2.8 \text { ) }\end{array}$} & 1 \\
\hline 2.1 & $\begin{array}{l}\text { Celkový rating kvality vysvětlení principů: (Tento celkový rating se získá použitím } \\
\text { posouzení založeného na hodnotách ratingů daných pro položky } 2.1 .1-2.1 .5)\end{array}$ & 3 \\
\hline 2.1 .1 & i) Teoretické základy konstruktů: & 4 \\
\hline 2.1 .2 & ii) Procedura vývoje testu: & 3,5 \\
\hline 2.1 .3 & iii) Důkladnost analýz položek a model analýzy položek: & 0 \\
\hline 2.1 .4 & iv) Vysvětlení obsahové validity: & 4 \\
\hline 2.1 .5 & v) Souhrn relevantního výzkumu: & 3,5 \\
\hline 2.2 & $\begin{array}{l}\text { Adekvátnost dokumentace dostupné uživateli (uživatelské a technické } \\
\text { manuály, dodatky týkající se norem atd.): (Tento celkový rating se získá použitím } \\
\text { posouzení založeného na hodnotách ratingů daných pro položky } 2.2 .1-2.2 .6 \text { ) } \\
\text { Pro část } 2.2 \text { jsou stanoveny následující „měřítka“ pro rating „vynikajíci““ (5). Pozornost je zde zaměřena } \\
\text { na kvalitu pokrytí poskytnutého v dokumentaci dostupné kvalifikovaným uživatelüm. Všimněte si, že část } \\
2.2 \text { se týká úplnosti a jasnosti dokumentace dostupné uživateli (uživatelské a technické manually, doadtky } \\
\text { k normám atd.) v pojmech pokrytí a vysvětlení. V pojmech kvality nástroje, jak ji dosvědčuje dokumentace, } \\
\text { jsou rozpracovány oblasti v této části pod čísly: } 2.1,2.3,2.9,2.10 \text { a } 2.11 \text {. }\end{array}$ & 1 \\
\hline
\end{tabular}


adaptace. Informace $\mathrm{o}$ validitě se rovněž vztahují pouze k validitě zahraniční studie, metoda vůbec nebyla ve své české adaptaci validizována. Autoři však alespoň uvádějí zdroje těchto informací.

Metoda poskytuje detailní návod k administraci a uspokojivé instrukce ohledně omezení používání testu určitými skupinami. Problematická je pouze absence doporučení, jak rychle (př́padně s jakou intonací) mají být čtené instrukce a podnětový materiál k subtestům na logickou pamět'. Manuál informuje, jak interpretovat souhrnné skóry. Varuje před výpočtem souhrnných skórů v případě signifikantních diskrepancí mezi jednotlivými subtesty, nenabízí však žádné vysvětlení pro takové př́pady. Manuál se vůbec nevěnuje návodu, jak poskytovat zpětnou vazbu a debriefing. Nezabývá se ani případným etnickým zkreslením a u zkreslení genderového pouze poukazuje na jeho existenci s tím, že zkreslení nemá klinický význam. Autoři se odkazují zejména na americkou verzi, ze které vycházejí, necitují však téměř žádnou literaturu navíc, ani nedoporučují další zdroje.

Materiály, které jsou součástí metody, jsou velmi kvalitně provedené, srozumitelné a praktické svou formou (metodu lze administrovat pomocí stojanu, na jehož jedné straně jsou instrukce pro administrátora a na druhé straně př́ípadný podnětový materiál). Kvalitu lokální adaptace testu lze však obtížně posoudit kvůli nedostatku informací, tím spíše nelze říci mnoho o kvalitě položek a jejich vhodnosti pro českou populaci.

\section{Část 7:}

\section{Hodnocení norem, reliability a validity}

Rating

\section{Informace o normách nebo referenční skupině}

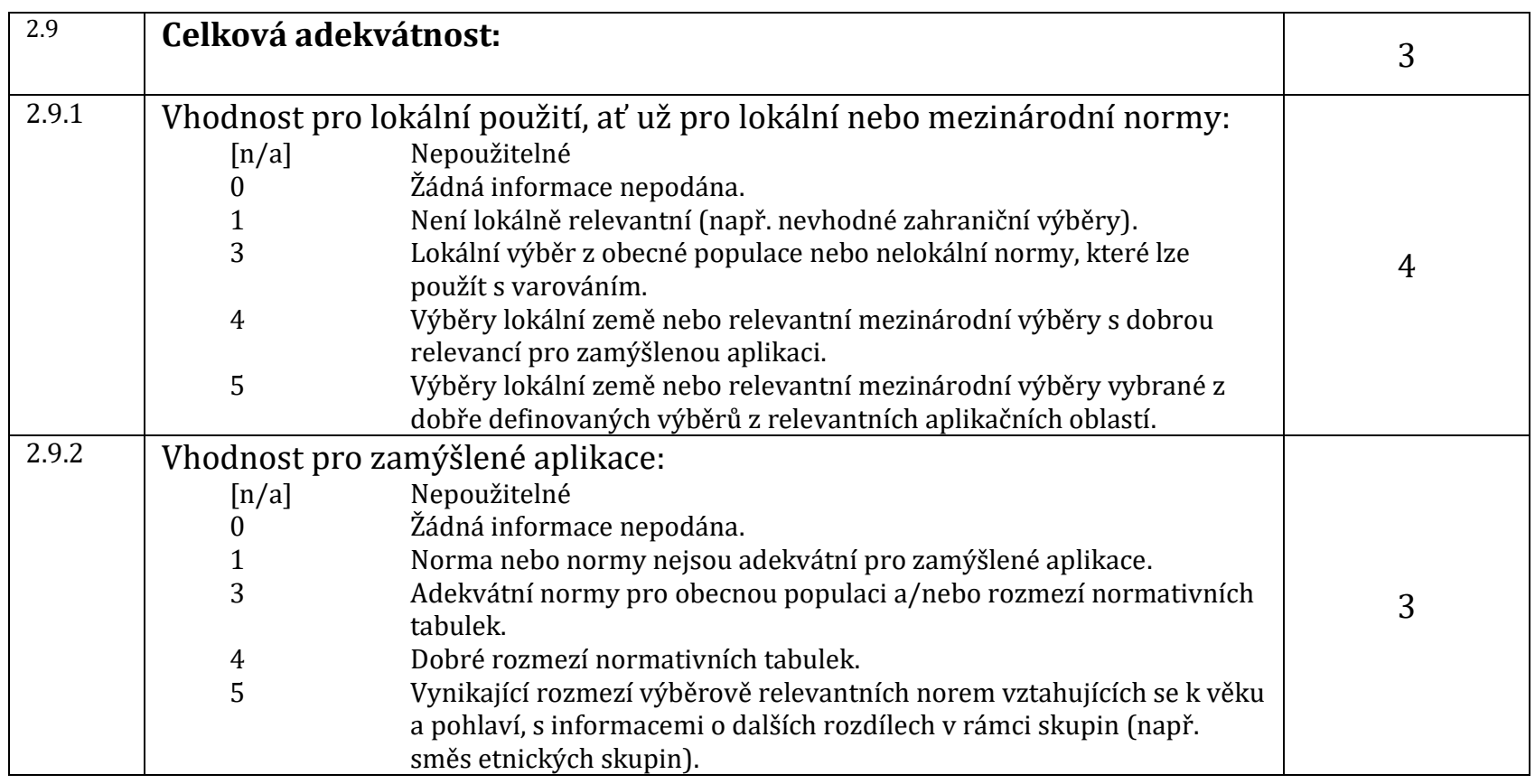




\section{Validita}

\begin{tabular}{|c|c|c|}
\hline 2.10 & $\begin{array}{l}\text { Celková adekvátnost: (Tento celkový rating se získá na základě posouzení hodnot ratingů } \\
\text { daných v položkách } 2.10 .1-2.10 .2 .4 \text {. Neprüměrujte pouze čísla, abyste získali celkový rating. } \\
\text { Obvykle bude roven bud' konstruktové validitě nebo validitě vztahující se ke kritériu, podle } \\
\text { toho, která z nich je vyšší.) }\end{array}$ & 1 \\
\hline 2.10 .1 & $\begin{array}{l}\text { Konstruktová validita - celková adekvátnost } \\
\text { (Tento celkový rating se získá na základě posouzení hodnot ratingů daných v položkách } \\
\text { 2.10.1.2 - 2.10.1.6. Neprůměrujte pouze čísla, abyste tento celkový rating získali.) }\end{array}$ & 4 \\
\hline 2.10 .1 .1 & 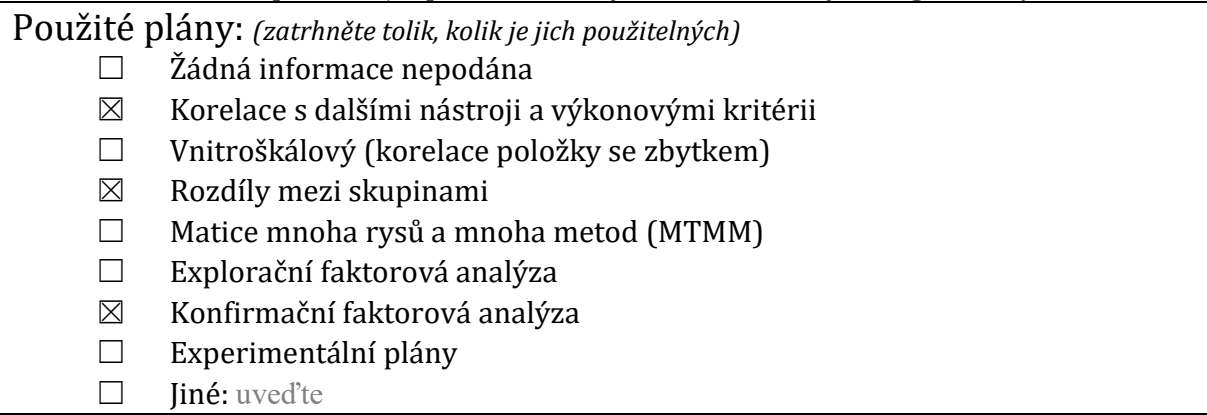 & \\
\hline 2.10 .1 .2 & $\begin{array}{cl}\begin{array}{c}\text { Velikosti výběrů: } \\
0\end{array} & \text { Žádná informace neposkytnuta. } \\
1 & \text { Jedna neadekvátní studie (např. velikost výběru menší než 100). } \\
3 & \text { Jedna adekvátní studie (např. velikost výběru 100-200). } \\
4 & \text { Více než jedna adekvátní nebo velká studie. } \\
5 & \text { Dobrá série adekvátních až rozsáhlých studií. }\end{array}$ & 4 \\
\hline 2.10 .1 .3 & $\begin{aligned} \text { Procedura výběru souboru: (vyberte jednu) } \\
\square \quad \text { Žadná informace neposkytnuta } \\
\square \quad \text { Reprezentativní vůči populaci [sumarizujte kritéria] } \\
\square \quad \text { Nahodilá } \\
\square \quad \text { Náhodná }\end{aligned}$ & \\
\hline 2.10 .1 .4 & $\begin{array}{cl}\text { Medián a rozsah korelací mezi testem a dalšími podobnými testy: } \\
0 & \text { Žádná informace neposkytnuta. } \\
1 & \text { Neadekvátní }(\mathrm{r}<0.55) . \\
3 & \text { Adekvátní }(0.55<\mathrm{r}<0.65) \\
4 & \text { Dobrý }(0.65<\mathrm{r}<0.75) . \\
5 & \text { Vynikající }(\mathrm{r}>0.75) \\
\end{array}$ & 3 \\
\hline 2.10 .1 .5 & $\begin{array}{cl}\text { Kvalita nástrojů jako kritérií nebo markerů: } \\
0 & \text { Žádná informace neposkytnuta. } \\
1 & \text { Poskytnuta neadekvátní informace. } \\
3 & \text { Adekvátní kvalita. } \\
4 & \text { Dobrá kvalita. } \\
5 & \text { Vynikající kvalita s širokým rozsahem relevantních markerů pro } \\
& \text { konvergentní a divergentní validizaci. } \\
\end{array}$ & 4 \\
\hline 2.10 .1 .6 & $\begin{array}{cl}\text { Analýzy diferenciálního fungování položek (DIF): } \\
{[\mathrm{N} / \mathrm{A}]} & \text { Nepoužitelné } \\
0-5 & \text { hodnocení kvality DIF analýzy } \\
\end{array}$ & 0 \\
\hline 2.10 .2 & $\begin{array}{l}\text { Validita vztahující se ke kritériu - celková adekvátnost } \\
\text { (Tento celkový rating se získá na základě posouzení hodnot ratingů daných v položkách } \\
2.11 .1-2.10 .2 .4 \text {. Neprủměrujte pouze čísla, abyste získali celkový rating.) }\end{array}$ & 4 \\
\hline 2.10 .2 .1 & $\begin{array}{l}\text { Popis použitých kritérií a charakteristik populací: (zatrhněte tolik, kolik je použitel } \\
\square \quad \text { Souběžná } \\
\square \quad \text { Prediktivní } \\
\square \quad \text { Postdiktivní }\end{array}$ & \\
\hline 2.10 .2 .2 & $\begin{array}{cl}\text { Velikosti výběrů: } \\
0 & \text { Žádná informace neposkytnuta. } \\
1 & \text { Jedna neadekvátní studie (např. velikost výběru menší než 100). } \\
3 & \text { Jedna adekvátní studie (např. velikost výběru 100-200). } \\
4 & \text { Jedna velká nebo vice než jedna adekvátně rozsáhlá studie. } \\
5 & \text { Dobrá série adekvátních až rozsáhlých studií. } \\
\end{array}$ & 4 \\
\hline
\end{tabular}




\begin{tabular}{|c|c|c|c|}
\hline 2.10.2.3 & $\begin{array}{r}\text { Procedu } \\
\text { (vyberte je } \\
\qquad \\
\square \\
\square \\
\square\end{array}$ & $\begin{array}{l}\text { a výběru souboru: } \\
\text { dnu) } \\
\text { Žádná informace neposkytnuta } \\
\text { Účelná nebo reprezentativní } \\
\text { Nahodilá } \\
\text { Náhodná }\end{array}$ & \\
\hline 2.10 .2 .4 & $\begin{array}{c}\text { Medián } \\
0 \\
1 \\
3 \\
4 \\
5\end{array}$ & $\begin{array}{l}\text { rozsah korelací mezi testem a kritérii: } \\
\text { Žádná informace neposkytnuta. } \\
\text { Neadekvátní (např. } \mathrm{r}<0.2 \text { ). } \\
\text { Adekvátní (např. } 0.2<\mathrm{r}<0.35 \text { ). } \\
\text { Dobrý (např. } 0.35<\mathrm{r}<0.50 \text { ). } \\
\text { Vynikající (např. } \mathrm{r}>0.50 \text { ) }\end{array}$ & 4 \\
\hline
\end{tabular}

\subsubsection{Komentáře recenzenta týkající se validity:}

Dílčí hodnocení je založeno na americké standardizační studii, která je jediným v manuálu uvedeným zdrojem důkazů o validitě české adaptace. Tyto údaje však nutně neznamenají, že validita je podobná u české verze metody, proto je naše celkové hodnocení nízké.

Wechsler (2011) při vydání třetí verze Wechslerovy pamět’ové škály spolu s její zkrácenou verzí publikoval sérii validizačních studií provedených v rámci americké standardizace. Ty se věnují souběžné, diskriminační, kriteriální a konstruktové validitě. Klinicky významný rozdíl mezi obtížností plné a zkrácené verze nalezen nebyl, souhrnné skóry WMS-IIIa by tedy měly odrážet WMS-III. WMSIIIa vysoce koreluje s jinými nástroji měření paměti. Vysoká korelace je uvedena např. pro MMSE a škály paměti a pozornosti $\mathrm{v}$ rámci Mattisovy škály demence. Naopak nízké korelace se ukázaly $\mathrm{v}$ souvislosti s expresí jazyka, ačkoliv je výkon WMS-IIIa zprostředkován verbálními schopnostmi.

Vzhledem k tomu, že WMS-IIIa je navržena k měření deklarativní paměti, předpokládala se její vysoká senzitivita na poruchy spojené s amnézií a demencí. Testovaly se proto rozdíly mezi různými klinickými skupinami (např. pacienti s Alzheimerovou chorobou, Parkinsonovou chorobou, roztroušenou sklerózou aj.). Zkrácená verze byla autory vyhodnocena jako senzitivní na různě závažná poškození paměti s tím, že však neumožňuje - a ani si neklade za cíl - rozlišení deficitů sluchové či zrakové paměti.

Faktorová validita byla testována pouze na nezkrácené verzi WMS-III, a to na zahraničních verzích (Millis et al., 1999; Price et al., 2002). Jejím smyslem byla volba subtestů k použití do zkrácené verze, lze ji ale zřejmě zobecnit i na WMS-IIIa.

Další informace přináší diplomová práce jedné z autorek metody (Jenčová, 2009), ve které byla testována kriteriální validita jako souvislost mezi WMS-IIIa a dalšími metodami, např. Pamět'ovým testem učení (AVLT), Číselnými řadami ISA či Testem cesty (TMT). Korelační analýza ukázala středně silné vztahy, tyto hodnoty je ale třeba považovat za orientační vzhledem k omezenému souboru (respondenti ve věku 20-39 let). 


\section{Reliabilita}

\begin{tabular}{|c|c|c|}
\hline 2.11 & $\begin{array}{l}\text { Celková adekvátnost: } \\
\text { (Tento celkový rating se získá na základě posouzení hodnot ratingů daných v položkách 2.11.1-2.10.2.4. } \\
\text { Neprůměrujte pouze čísla, abyste získali celkový rating.) }\end{array}$ & 1 \\
\hline 2.11.1. & $\begin{array}{l}\text { Poskytnutá data týkající se reliability: (vyberte jednu možnost) } \\
\square \quad \text { Uveden pouze jeden koeficient reliability } \\
\square \quad \text { Uveden pouze jeden odhad standardní chyby měření } \\
\bigotimes \quad \text { Koeficienty reliability pro několik různých skupin } \\
\square \quad \text { Standardní chyba měření uvedená pro několik různých skupin }\end{array}$ & \\
\hline 2.11 .1 & Vnitřní konzistence: & \\
\hline 2.11.1.1 & $\begin{array}{cl}\text { Velikost výběru: } \\
0 & \text { Neposkytnuta žádná informace. } \\
1 & \text { Jedna neadekvátní studie (např. rozsah výběru menší než 100). } \\
3 & \text { Jedna adekvátní studie (např. rozsah výběru 100-200). } \\
4 & \text { Jedna rozsáhlá nebo vice než jedna adekvátně rozsáhlá studie. } \\
5 & \text { Dobrá série adekvátních až rozsáhlých studií. } \\
{[\mathrm{N} / \mathrm{A}]} & \text { Nepoužitelné. }\end{array}$ & 4 \\
\hline 2.11.1.2 & $\begin{array}{ll}\text { Medián koeficientů: } \\
0 & \text { Neposkytnuta žádná informace. } \\
1 & \text { Neadekvátní (např. } r<0.7 \text { ) } \\
3 & \text { Adekvátní (např. } r=0.7 \text { až } 0.79 \text { ) } \\
4 & \text { Dobrý (např. } r=0.8 \text { až } 0.89 \text { ) } \\
5 & \text { Vynikající (např. } r>0.9 \text { ) } \\
{[\mathrm{N} / \mathrm{A}]} & \text { Nepoužitelné. }\end{array}$ & 3 \\
\hline 2.11 .2 & Testová-retestová stabilita: & \\
\hline 2.11.2.1 & $\begin{array}{cl}\text { Rozsah výběru: } & \\
0 & \text { Neposkytnuta žádná informace. } \\
1 & \text { Jedna neadekvátní studie (např. rozsah výběru menší než 100). } \\
3 & \text { Jedna adekvátní studie (např. rozsah vy̌běru 100-200). } \\
4 & \text { Jedna rozsáhlá nebo vice než jedna adekvátně rozsáhlá studie. } \\
5 & \text { Dobrá série adekvátních až rozsáhlých studií. } \\
\end{array}$ & 0 \\
\hline 2.11 .2 .2 & $\begin{array}{cl}\text { Medián koeficientů: } \\
0 & \text { Neposkytnuta žádná informace. } \\
1 & \text { Neadekvátní (např. } \mathrm{r}<0.6 \text { ) } \\
3 & \text { Adekvátní (např. } \mathrm{r}=0.6 \text { až } 0.69 \text { ) } \\
4 & \text { Dobrý (např. } \mathrm{r}=0.7 \text { až } 0.79 \text { ) } \\
5 & \text { Vynikající (např. } \mathrm{r}>0.8 \text { ) } \\
\end{array}$ & 0 \\
\hline 2.11 .3 & Reliabilita jako ekvivalence: & \\
\hline 2.11.3.1 & $\begin{array}{cl}\text { Rozsah výběru: } & \\
0 & \text { Neposkytnuta žádná informace. } \\
1 & \text { Jedna neadekvátní studie (např. rozsah výběru menší než 100). } \\
3 & \text { Jedna adekvátní studie (např. rozsah výběru 100-200). } \\
4 & \text { Jedna rozsáhlá nebo vice než jedna adekvátně rozsáhlá studie. } \\
5 & \text { Dobrá série adekvátních až rozsáhlých studií. } \\
{[\mathrm{N} / \mathrm{A}]} & \text { Nepoužitelné. }\end{array}$ & 0 \\
\hline 2.11.3.2 & $\begin{array}{ll}\text { Medián koeficientů: } \\
0 & \text { Neposkytnuta žádná informace. } \\
1 & \text { Neadekvátní (např. } r<0.6 \text { ) } \\
3 & \text { Adekvátní (např. } r=0.6 \text { až } 0.69 \text { ) } \\
4 & \text { Dobrý (např. } r=0.7 \text { až } 0.79 \text { ) } \\
5 & \text { Vynikající (např. r }>0.8 \text { ) } \\
{[\mathrm{N} / \mathrm{A}]} & \text { Nepoužitelné }\end{array}$ & 0 \\
\hline \multicolumn{3}{|c|}{$\begin{array}{l}\text { 2.11.4 Komentáře recenzentů k reliabilitě: } \\
\text { - Komentujte intervaly spolehlivosti pro koeficienty reliability } \\
\text { - Uved'te Spearmanovy-Brownovy ekvivalenty }\end{array}$} \\
\hline \multicolumn{3}{|c|}{$\begin{array}{l}\text { V manuálu metody autoři reportují různé koeficienty reliability. Prvním je split-half reliabilita } \\
\text { jednotlivých subtestů, u které však autoři uvedli, že ji na datech k české standardizaci z nezmíněných } \\
\text { důvodů nebylo možné spočítat. Namísto toho uvedli hodnoty dosažené v americké standardizaci } \\
(0,79-0,88) \text {. Autoři české adaptace v manuálu dále uvádějí Cronbachův koeficient alfa pro souhrnné } \\
\text { skóry, který se pohyboval v rozmezí } 0,70-0,86 \text { napríč věkovými skupinami. Tyto hodnoty jsou nižší }\end{array}$} \\
\hline
\end{tabular}


než v rámci americké standardizační studie, kde koeficienty dosahovaly hodnot 0,87-0,92. Testretestovou reliabilitu česká standardizační studie neposkytuje, protože nebyla prováděna žádná následná měření. Autoři proto reportují koeficienty získané při americké standardizaci $(0,61-0,80$ pro skóry subtestů, $0,71-0,81$ pro souhrnné skóry). Jako poslední je uveden koeficient shody mezi posuzovateli převzatý z americké standardizace, který dle autorů přesáhl hodnotu 0,90 . K hodnocení shody byla provedena skórovací studie, ve které bylo dvakrát nezávisle vyhodnoceno deset protokolů pro každou věkovou skupinu. $V$ českém manuálu však není uvedeno, který koeficient shody byl pro výpočet zvolen. Česká adaptace navíc používá v subtestech Logická pamět' I a II vlastní př́běhy, drobné jazykové nuance skórování proto nemusí být ošetřené.

Jediným údajem vypovídajícím o české adaptaci testu tedy zůstává Cronbachova alfa. Ta je vypočítána pro souhrnné skóry jednotlivých věkových skupin, pro něž autoři uvádějí standardní chyby měření. Pro výpočet Cronbachovy alfy použili namísto položkových dat souhrnné skóry subtestů, což nutně vede k silnému podhodnocení celkové reliability. Tím lze vysvětlit také to, proč je reliabilita nižší ve srovnání s americkou standardizační studií. Manuál pak sice poskytuje přehlednou tabulku intervalů spolehlivosti pro výsledky $\mathrm{v}$ jednotlivých věkových skupinách, tyto hodnoty však vyplývají $\mathrm{z}$ nevhodného způsobu výpočtu reliability.

Za hlavní slabiny hodnocení reliability lze považovat nezdůvodňování, chybějící informace a postup, jakým byla vypočítána. Protože je česká adaptace WMS-IIIa strukturována stejně jako originální verze, lze údaje o reliabilitě originálu vnímat jako orientační. Reliabilitu české adaptace však nelze adekvátně posoudit, je třeba dalších návazných studií.

\section{Část 9:}

\section{Závěrečné hodnocení:}

\subsection{Hodnotící zpráva testu: \\ Tato část by měla obsahovat stručné, jasně obhájené posouzení nástroje/produktu. Mělo by popisovat jeho pro a proti a poskytnout určitá obecná doporučení týkající se toho, jak a kdy by se měl používat - spolu s varováními (kde jsou potřebná) týkajícími se př́padů, kde by se používat neměl.}

Českou adaptaci této rozšriřené pamětové škály lze těžko ohodnotit, a to primárně z důvodu nedostatku informací. Jediných ukazatelem reliability, který byl na české adaptaci posouzen, byla vnitřní konzistence testu, jejíž způsob výpočtu pravděpodobně zapř́íčinil snížení její hodnoty oproti původní americké standardizační studii. Další ukazatele, např. test-retestová realibilita, split-half reliabilita jednotlivých subtestů a shoda posuzovatelů, nebyly na české adaptaci testovány. Zejména chybějící informace o shodě posuzovatelů se mohou ukázat jako problematické, a to kvůli změnám v překladu oproti původní anglické verzi.

Další nedostatek spatřujeme v absenci ověření validity české adaptace testu. Český uživatel testu by si měl být vědom, že informace uvedené v manuálu vyplývají pouze $\mathrm{z}$ americké standardizace, což automaticky neimplikuje stejné fungování testu na české populaci. Je také nutno dodat, že zhodnocení norem vytvořených na české populaci je ztíženo chybějícími informacemi o standardizačním souboru a způsobu jeho výběru. Nyní dostupné informace tak poukazují na nedostatečnost českých norem.

Oceňujeme však překlad a kvalitu testových materiálů. Položky a instrukce metody WMS-IIIa jsou jasné a srozumitelné, popis administrace včetně skórování a interpretace testu je podrobný. Pozornost by se měla přesunout $\mathrm{k}$ funkčnosti WMS-IIIa $\mathrm{v}$ českém prostředí a $\mathrm{k}$ podrobnému testování jejích psychometrických vlastností. WMS-IIIa by se dala označit za metodu s velkým potenciálem, na což poukazují psychometrické vlastnosti původní anglické verze. Velkou slabinu české verze WMS-IIIa tedy nevidíme $\mathrm{v}$ metodě samotné, ale $\mathrm{v}$ české standardizační studii a nedůsledné psychometrické analýze. 


\subsection{Závěry:}

V literatuře je větší prostor věnován nezkráceným verzím Wechslerových pamět'ových šál (viz Kent, 2013), doporučovaly bychom proto její další testování a vývoj. Je možné tuto metodu použít expertním uživatelem za pečlivě kontrolovaných podmínek nebo ve velmi omezených aplikačních oblastech za předpokladu, že uživatel testu bude obezřetný v interpretaci výsledků.

\subsection{Doporučení (vyberte jedno)}

Všechny následující charakteristiky uvedené níže by měly mít ratingy [n/a], [2], [4], [5], pokud by měl být nástroj „doporučen“ pro obecné použití (hodnocení 5 nebo 6):

[2.9] Normy a referenční skupiny

[2.10.1] Konstruktová validita

[2.10.2] Kriteriální validita

[2.11] Reliabilita - celková

[2.12] Počítačově generované

zprávy

Pokud má kterýkoli z výše uvedených ratingů hodnotu [ ] nebo [1], nástroj by měl být klasifikován pod doporučením 1, 2, 3 nebo 4, nebo klasifikován pod doporučením 7 "jiné" s adekvátním vysvětlením.
1 Pouze výzkumný nástroj. Ne pro užití v praxi.

\ 2 Vhodný pouze pro užití expertním uživatelem za pečlivě kontrolovaných podmínek nebo ve velmi omezených aplikačních oblastech

3 Vhodný pro použití pod supervizí $\mathrm{v}$ aplikační(ch) oblasti(ech) definovaných distributorem, libovolnými uživateli $\mathrm{s}$ obecnými kompetencemi pro používání a administraci testů

4 Vyžaduje další vývoj. Vhodný pouze pro použití ve výzkumu.

5 Vhodný pro používání vaplikační(ch) oblasti(ech) definovaných distributorem, uživateli testů, kteří splňují speciální kvalifikační požadavky distributora

6 Vhodný pro sebevyšetření bez supervise $\mathrm{v}$ aplikační(ch) oblasti(ech) definovaných distributorem

7 Jiné:

\section{Odkazy k poznámkám a bibliografie}

Axelrod, B. N., \& Woodard, J. L. (2000). Parsimonious prediction of Wechsler Memory Scale-III Memory Indices. Psychological Assessment, 12(4), 431-435.

Jenčová, A. (2009). Wechslerova pamětová škála-třetí vydání, zkrácená verze. Retrieved from dspace.cuni.cz.

Kent, P. (2013). The evolution of the Wechsler Memory Scale: A selective review. Applied Neuropsychology: Adult, 20(4), 277-291.

Millis, S. R., Malina, A. C., Bowers, D. A., \& Ricker, J. H. (1999). Confirmatory factor analysis of the Wechsler Memory Scale-III. Journal of Clinical and Experimental Neuropsychology, 21(1), 87-93.

Price, L. R., Tulsky, D., Millis, S., \& Weiss, L. (2002). Redefining the factor structure of the Wechsler Memory Scale-III: Confirmatory factor analysis with cross-validation. Journal of Clinical and Experimental Neuropsychology, 24(5), 574-585.

Wechsler, D. (2011). Wechslerova zkrácená pamětová škála WMS-IIIa. Praha: Hogrefe - Testcentrum. Měřené konstrukty:

Bezprostřední pamět', oddálená pamět', celková pamět'. 